Research article

\title{
Effect of Mancozeb on Mustard (Brassica juncea L.): An In-vitro study
}

\author{
Monika* and Mohd. Kashif Kidwai \\ Department of Energy and Environment Sciences, Chaudhary Devi Lal University, Sirsa, Haryana, India \\ *Corresponding Author: monikakaswan88@gmail.com \\ [Accepted: 15 February 2017]
}

\begin{abstract}
Pesticides are extensively used all over the globe for the control of pest population responsible for reduction in yield and among them fungicides are the specifically used to control fungal plant pathogens. An In-vitro plant study was conducted to assess the effect of Mancozeb on early growth parameters on two Mustard (Brassica juncea) varieties i.e. RH- 30 and Laxmi. Mancozeb (75\% WP) is a widely applied contact fungicide for control of various diseases but several toxicity issues are associated with Mancozeb. Mustard is one of the most important oil yielding crops and is majorly used for various purposes such as medicinal uses, condiment and industrial uses. In the experiment three different doses of Mancozeb (75\% WP) i.e. $1 \mathrm{mg} . \mathrm{kg}^{-1} \mathrm{Half}$ Recommended Dose (1/2RD), 2 mg. $\mathrm{kg}^{-1}$ Recommended Dose (RD) and $4 \mathrm{mg} \cdot \mathrm{kg}^{-1}$ Double Recommended Dose (2RD) applied on RH-30 and Laxmi varieties. Results revealed that, RD and $2 \mathrm{RD}$ reduced the germination up to $30-60 \%$ in variety $\mathrm{RH}-30$ whereas in variety Laxmi reduced germination percentage is $17-55 \%$ in comparison of control. The overall length of plants of variety Laxmi was found to be increased in comparison of control but in plants of variety $\mathrm{RH}-30$ the results was just opposite. Overall results indicate that excess amount of Mancozeb induced stress in both mustard varieties which resulted in low germination percentage. Whereas after seven days, Laxmi resulted in better growth than RH-30 plants. Also, Seeding vigour was recorded higher in Laxmi than RH-30.
\end{abstract}

Keywords: Pesticides - Fungicides - Seeding Vigour - Mustard.

[Cite as: Monika \& Kidwai MK (2017) Effect of Mancozeb on Mustard (Brassica juncea L.): An In-vitro study. Tropical Plant Research 4(1): 55-61]

\section{INTRODUCTION}

Mustard (Brassica juncea L.) is one of the most important oil crops of the world after soybean and groundnut (FAO 2012) and in India it is popularly cultivated as major oil seed crop (Meena et al. 2010). It is predominantly cultivated in the states of Rajasthan, Uttar Pradesh, Haryana, Madhya Pradesh and Gujarat which contribute $81.5 \%$ in terms of area and $87.5 \%$ in term of production and majorly used for various purposes such as medicinal uses, condiment, and industrial uses. Mustard is rich in phytonutrients, minerals, vitamins and antioxidants as well as constituents like sinalbin and sinigrin and serves as a functional food (Kumar \& Andy 2012). According to Ayurveda, Mustard leaf is considered as a vegetable, while the seeds are used as a condiment and constitute the source of mustard oil. Mustard seed is considered as rich source of oil and protein. The seed has oil content as high as $46-48 \%$ while seed meal has $43.6 \%$ protein (use of meal) and low in glucosinolate content. Also, seed residue used as an ingredient for cattle feed and poultry feed in India (Mandal et al. 2002, Manohar et al. 2009).

Some anti-nutritional factors present in rapeseed-mustard crops are known to be associated with some plant defence system and other important biological functions (Kumar et al. 2014).

Application of pesticide is strategy for effective management of pests and diseases and the productivity of crops depends on their effective control (Pretty \& Bharucha 2015). Pesticides are extensively used all over the globe to control different pest population and among them fungicides are specially used for control fungal plant pathogens (Mancini \& Romanazzi 2013). In the past few, non-target environmental impact and Excessive use of 
fungicides have caused environmental pollution and development of fungicide resistance in plant pathogens which led to the search for alternative methods (Hollomon 2015). In recent years, crop suffers from many diseases out of them Alternaria blight [Alternaria brassicae (Berk.) Sacc. \& A. brassicicola (Schw.)] is one of the serious and widely occurred diseases all over the country (Meena et al. 2011, Chaurasia \& Bhajan 2015). Alternaria blight is reported to causes blight of leaf, pod, stem and seed abnormalities (Chattopadhyay et al. 2005). It is reported that Alternaria blight reduce upto $70 \%$ yield of mustard in India (Rathi et al. 2015).

Table 1. Physical and Chemical Properties of Mancozeb as described by (Harvest 2016).

\begin{tabular}{|c|c|}
\hline Chemical Name & Manganese ethylenebis (dithocarbamate) (polymeric) complex with zinc salt \\
\hline Empirical Formula & $\left(\mathrm{C}_{4} \mathrm{H}_{6} \mathrm{MnN}_{2} \mathrm{~S}_{4}\right)_{\mathrm{x}}(\mathrm{Zn})_{\mathrm{y}}$ \\
\hline Molecular Weight & 541 \\
\hline Structural Formula & 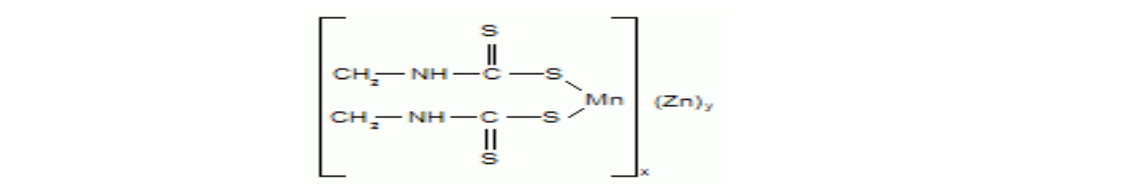 \\
\hline Flashing point & $138^{\circ} \mathrm{C}\left(150^{\circ} \mathrm{C} \mathrm{Dec}.\right)$ \\
\hline Solubility & $6-20 \mathrm{mg} . \mathrm{l}^{-1}$ in water, practically insoluble in most organic solvents \\
\hline Vapour pressure & Negligible \\
\hline Acute oral LD50 & 5 g. $\mathrm{kg}^{-1}$ (rat) \\
\hline Mancozeb formulation & $75 \% \mathrm{WP}$ \\
\hline
\end{tabular}

Mancozeb (75\% WP) is a contact fungicide mainly used for control various diseases on wide variety of crops (Jankowski 2007, Mathivanan \& Prabhavati 2007). Mancozeb [[1, 2-ethanediylbis-[carbamodithio- ato]] (2- )] manganese, mixture with [[1, 2-etha-nediylbis-[carbamodithioato]]-(2- )] zinc is a fungicide of the carbamate pesticide family. It is marketed by the trade names Dithane M45, Indofill, Manzeb, Nemispot, Manzane etc. It is applied on various crops including oil bearing plants and field crops against a wide spectrum of fungal diseases (Nirwan et al. 2016). The fungicide Mancozeb 75\% WP [Indofil M-45] was used in the present study.

Table 2. Diseases controlled by fungicide Mancozeb on Mustard (Brassica juncea L.).

\begin{tabular}{|c|c|c|}
\hline Diseases & Causal organism & References \\
\hline Sclerotinia rot & Sclerotinia sclerotiorum (Lib.) de Bary & $\begin{array}{l}\text { Biswas et al. (2007), } \\
\text { Vishwanath \& Kolte (1997) }\end{array}$ \\
\hline White rust & Albugo cruciferarum (Gray) Kuntze & Bhatia \& Gangopadhyay (2008) \\
\hline Alternaria blight & $\begin{array}{l}\text { Alternaria brassicae (Berk.) Sacc. } \\
\text { and } A \text {. brassicicola (Schw) Wiltshire }\end{array}$ & Meena et al. (2011) \\
\hline Powdery mildew & Erysiphe cruciferarum Opiz ex L. Junell & $\begin{array}{l}\text { Biswas et al. (2007), } \\
\text { Vishwanath \& Kolte (1997) }\end{array}$ \\
\hline Downy mildew complex & $\begin{array}{l}\text { Hyaloperonospora parasitica (Pers.) } \\
\text { Constant. }\end{array}$ & $\begin{array}{l}\text { Biswas et al. (2007), } \\
\text { Vishwanath \& Kolte (1997) }\end{array}$ \\
\hline
\end{tabular}

Mancozeb is applied on various crops against a wide spectrum of fungal diseases (Hayes \& Paiford 1995, Goswami \& Ghosh 2012). Mancozeb has power to inhibit spore formation in pathogenic fungi thereby causing its death (Elsamen et al. 2015). Mancozeb is reported to be associated with several health hazards when applied in very high doses. The resulting symptoms are convulsions, slurred speech, confusion, slowed heartbeat etc. Mancozeb is reported to be an established carcinogen (FAO/WHO 1993, Vettorazzi et al. 1995, Liu et al. 2016). Mancozeb is reported to cause teratogenic, carcinogenic and goitrogenic effects on mammals. Ethylene thio urea (ETU), carbon disulphide $\left(\mathrm{CS}_{2}\right)$, thio urea etc are metabolites produced in degradation of Mancozeb reported to be responsible for inducing thyroid toxicity and neurotoxicity (Kackar et al. 1997, Domico et al. 2007, Miller et al. 2009). ETU is reported to cause ground water pollution due to its high solubility in water (Belpoggi et al. 2002, Srivastava \& Singh 2013). The fungicide Mancozeb has a considerable deleterious impact on soil microflora, nitrification, ammonification, soil microbial biomass, carbon mineralization and soil enzymes which may result in harmful effects on nutrient uptake and plant growth. These findings suggest that the use of Mancozeb to control plant diseases in apple orchard soil requires simultaneous application of large quantities of nitrogen based fertilizers (Dias 2012). 
There is very little information available with regard to the effect of fungicide on oil crops generally and on Mustard crop particularly. Therefore the present study was undertaken with a view to understand the effect of commonly used fungicide Mancozeb on initial plant growth and chlorophyll content of Mustard (Brassica juncea L.).

\section{MATERIAL AND METHODS}

The present study was conducted at the laboratory of Environment Toxicology and Microbiology, Department of Energy and Environmental Science of Chaudhary Devi Lal University, Sirsa. Soil sample was collected from the fertile field of village Umedpura of District Sirsa. In this field, wheat, cotton and mustard are mainly cultivated crops. The soil was processed in Laboratory, excess moisture was removed by drying the soil in shade and sieved properly to make it usable for pot trial study. The pots were prepared by 100 gm soil in each pot, and this study was triplicated for each treatment (Kidwai 2007). Fungicide Mancozeb 75\% WP [Indofil M45] was procured from local market of Sirsa. The three different doses of fungicide i.e. half recommended dose, recommended dose and double recommended dose were used in this study.

Table 3. Different doses of Mancozeb 75\% WP with their application rate used for seed treatment.

\begin{tabular}{lc}
\hline Doses & Application rate (per kg seed) \\
\hline Half recommended dose (1/2RD) & $1 \mathrm{mg} \cdot \mathrm{kg}^{-1}$ \\
Recommended dose (RD) & $2 \mathrm{mg} \cdot \mathrm{kg}^{-1}$ \\
Double recommended dose (2RD) & $4 \mathrm{mg} \cdot \mathrm{kg}^{-1}$ \\
\hline
\end{tabular}

Seed of two popular mustard varieties i.e. RH-30 and Laxmi (procured from Krishi Vigyan Kendra, Sirsa) were surface sterilized with $0.1 \% \mathrm{HgCl}_{2}$ (mercuric chloride) for $5 \mathrm{~min}$ then washed thoroughly with distilled water (Hirve \& Bafna 2013) and allowed to germinate in pots. Three sets in each dose were maintained along with the control for comparative study. On the seventh day, growth parameters and chlorophyll content were evaluated. Germination percentage was estimated as described by Rangwala et al. (2013),

$$
\text { Germination } \%=\frac{\text { Number of seeds germinated }}{\text { Total number of seeds }} \times 100
$$

Root and shoot length of seedlings were recorded using the standard centimetre scale (Kabir et al. 2008, Rangwala et al. 2013). Seedling Vigour index was calculated applying formula suggested by Aery (2010),

$$
\text { Vigour index }=\frac{\text { Germination } \%}{\text { Total length (root length }+ \text { shoot length) } i n \mathrm{~cm}}
$$

Three plants of each treatment were weighed in order to determine the fresh weight (Kabir et al. 2008, Rangwala et al. 2013). Spectrophotometric estimation of the Chlorophyll 'a', Chlorophyll 'b' and total Chlorophyll of mustard crop was done by following the method as described by Aery (2010).

$$
\begin{aligned}
& \text { Chlorophyll 'a' }\left(\mathrm{mg} \cdot \mathrm{g}^{-1}\right)=12.7 \mathrm{~A}_{663}-2.69 \mathrm{~A}_{645} \times \mathrm{V} / 1000 \times \mathrm{W} \\
& \text { Chlorophyll 'b' }\left(\mathrm{mg} \cdot \mathrm{g}^{-1}\right)=22.9 \mathrm{~A}_{645^{-}}-4.68 \mathrm{~A}_{663} \times \mathrm{V} / 1000 \times \mathrm{W} \\
& \text { Total Chlorophyll }\left(\mathrm{mg} \cdot \mathrm{g}^{-1}\right)=27.8 \mathrm{~A}_{662} \times \mathrm{V} / 1000 \times \mathrm{W}
\end{aligned}
$$

Where, $\mathrm{V}=\mathrm{Vol}$. of the extract in $\mathrm{ml}, \mathrm{A}_{645}=$ Optical density measured at $645 \mathrm{~nm}, \mathrm{~A}_{663}=$ Optical density measured at $663 \mathrm{~nm}$ and $\mathrm{A}_{662}=$ Optical density measured at $662 \mathrm{~nm}$.

Table 4. Codes for the Treatment used in the study.

\begin{tabular}{ll}
\hline Treatments (T) & Code \\
\hline Control RH-30 & $\mathrm{TR}_{1}$ \\
Control Laxmi & $\mathrm{TL}_{1}$ \\
Half Recommended Dose of Mancozeb ( RH-30) & $\mathrm{TR}_{2}$ \\
Half Recommended Dose of Mancozeb (Laxmi) & $\mathrm{TL}_{2}$ \\
Recommended Dose of Mancozeb (RH-30 & $\mathrm{TR}_{3}$ \\
Recommended Dose of Mancozeb ( Laxmi) & $\mathrm{TL}_{3}$ \\
Double Recommended Dose of Mancozeb ( RH-30) & $\mathrm{TR}_{4}$ \\
Double Recommended Dose of Mancozeb (Laxmi) & $\mathrm{TL}_{4}$ \\
\hline
\end{tabular}




\section{RESULTS AND DISCUSSION}

Table 5. Variation in early growth parameter and chlorophyll content in Mustard varieties.

\begin{tabular}{|c|c|c|c|c|c|c|c|}
\hline $\mathbf{T}$ & $\begin{array}{l}\text { Germination } \\
\%\end{array}$ & $\begin{array}{l}\text { Fresh } \\
\text { weight } \\
\text { (gm) }\end{array}$ & $\begin{array}{l}\text { Total } \\
\text { length } \\
(\mathrm{cm}) \\
\end{array}$ & $\begin{array}{l}\text { Seedling } \\
\text { Vigour } \\
\text { Index } \\
\end{array}$ & $\begin{array}{l}\text { Chl 'a' } \\
\left(\mathrm{mg}^{\prime} \mathrm{g}^{-1}\right)\end{array}$ & $\begin{array}{l}\text { Chl 'b' } \\
\left(\mathrm{mg}^{\prime} \mathrm{g}^{-1}\right)\end{array}$ & $\begin{array}{l}\text { Chl 'total' } \\
\left(\mathrm{mg} \cdot \mathrm{g}^{-1}\right)\end{array}$ \\
\hline $\mathbf{T R}_{1}$ & $80 \pm 0.2$ & $0.82 \pm .01$ & $6.8 \pm .005$ & $544 \pm .057$ & $0.502 \pm .0005$ & $0.248 \pm .0005$ & $0.742 \pm .0005$ \\
\hline $\mathbf{T R}_{2}$ & $\begin{array}{l}70 \pm .25 \\
(13)\end{array}$ & $\begin{array}{l}0.81 \pm .005 \\
\text { (1) }\end{array}$ & $\begin{array}{l}6.4 \pm .01 \\
(6)\end{array}$ & $\begin{array}{l}448 \pm .15 \\
(18)\end{array}$ & $\begin{array}{l}0.463 \pm .001 \\
(8)\end{array}$ & $\begin{array}{l}0.228 \pm .001 \\
(8)\end{array}$ & $\begin{array}{l}0.643 \pm .002 \\
(13)\end{array}$ \\
\hline $\mathbf{T R}_{3}$ & $\begin{array}{l}60 \pm .05 \\
(25)\end{array}$ & $\begin{array}{l}0.71 \pm .01 \\
(13)\end{array}$ & $\begin{array}{l}6.1 \pm .05 \\
(10)\end{array}$ & $\begin{array}{l}366 \pm 1 \\
(33)\end{array}$ & $\begin{array}{l}0.428 \pm .001 \\
(15)\end{array}$ & $\begin{array}{l}0.201 \pm .002 \\
(19)\end{array}$ & $\begin{array}{l}0.599 \pm .003 \\
(19)\end{array}$ \\
\hline $\mathbf{T R}_{4}$ & $\begin{array}{l}50 \pm 2 \\
(38)\end{array}$ & $\begin{array}{l}0.43 \pm .22 \\
(48)\end{array}$ & $\begin{array}{l}3.1 \pm .2 \\
(54)\end{array}$ & $\begin{array}{l}155 \pm 4 \\
(72)\end{array}$ & $\begin{array}{l}0.201 \pm .001 \\
(60)\end{array}$ & $\begin{array}{l}0.083 \pm .001 \\
(67)\end{array}$ & $\begin{array}{l}0.219 \pm .11 \\
(70)\end{array}$ \\
\hline $\mathbf{T L}_{1}$ & $90 \pm 2$ & $0.89 \pm .03$ & $8.6 \pm 0.4$ & $774 \pm 1$ & $0.691 \pm .01$ & $0.535 \pm .005$ & $0.751 \pm .001$ \\
\hline $\mathbf{T L} \mathbf{L}_{2}$ & $\begin{array}{l}80 \pm .05 \\
(0.11)\end{array}$ & $\begin{array}{l}0.88 \pm .03 \\
\text { (1) }\end{array}$ & $\begin{array}{l}8.5 \pm .15 \\
(1)\end{array}$ & $\begin{array}{l}680 \pm 8 \\
(12)\end{array}$ & $\begin{array}{l}0.68 \pm .01 \\
(2)\end{array}$ & $\begin{array}{l}0.531 \pm .001 \\
\text { (1) }\end{array}$ & $\begin{array}{l}0.747 \pm .002 \\
\text { (1) }\end{array}$ \\
\hline $\mathbf{T L}_{3}$ & $\begin{array}{l}70 \pm .5 \\
(22)\end{array}$ & $\begin{array}{l}0.85 \pm .01 \\
(4)\end{array}$ & $\begin{array}{l}7.1 \pm .1 \\
(17)\end{array}$ & $\begin{array}{l}497 \pm 4 \\
(36)\end{array}$ & $\begin{array}{l}0.677 \pm .002 \\
\text { (2) }\end{array}$ & $\begin{array}{l}0.527 \pm .01 \\
(1)\end{array}$ & $\begin{array}{l}0.698 \pm .01 \\
\text { (7) }\end{array}$ \\
\hline $\mathbf{T L}_{4}$ & $\begin{array}{l}60 \pm 1 \\
(33)\end{array}$ & $\begin{array}{l}0.61 \pm .01 \\
(31)\end{array}$ & $\begin{array}{l}4.2 \pm .1 \\
(51)\end{array}$ & $\begin{array}{l}252 \pm 1 \\
(67)\end{array}$ & $\begin{array}{l}0.311 \pm .001 \\
(55)\end{array}$ & $\begin{array}{l}0.209 \pm .05 \\
(61)\end{array}$ & $\begin{array}{l}0.354 \pm .1 \\
(53)\end{array}$ \\
\hline
\end{tabular}

Note: * All the values are mean of triplicate value, figure in parenthesis indicates percent decrease in comparison of control.

The fungicide Mancozeb has highly influenced all the studied growth parameters of mustard seedlings. Germination percentage of Mancozeb fungicide treated seed was decreased with the increase in concentration of fungicide Mancozeb. Other studies also reported that more fungicide produces negative interference and abiotic stress in germination of seeds and decreased it drastically in the treated sets (Horii et al. 2007, Cataneo et al. 2010, Marini et al. 2011, Parween et al. 2016). The results of our present study were conflict to Benicio (2015) who reported that fungicides doses not produces interference in germination of seeds.

The results of present study demonstrated that shoot and root length was decreased with increasing concentration of fungicide. Petit et al. (2012), Anitha \& Savitha (2013) and Shakir et al. (2016) were also reported that growth of plants was reduced after increasing the dose of Mancozeb fungicides. Results were in agreement with the work done by Windham \& Windham (2004), Bensoltane et al. (2006) and Mohammed \& Alrajh (2014) who have reported that Mancozeb is a systemic fungicides which are based on sterol biosynthesis inhibitor are closely related to plant growth regulators the use of which at higher than labeled rates shorten the internodes which may lead to slow-shoot and root growth.

Seedling vigour index was decreased at almost all the concentration of fungicide as compared to control in the present study. But the results of our present study were contrary to Morales et al. (2012) who observed higher vigour of rice seeds treated with Carboxin and Thiram fungicides.

In the study, results of mustard seedlings treated with Mancozeb indicate decrease in fresh weight with increasing concentration of fungicide. These results were in parallel with the findings of Avinash \& Hoshmani (2012) that fresh weight of leaves of sorghum seeds treated with Carbendazim decrease with increase in concentration of fungicide.

Chlorophyll content were also reduced in the study as increased in concentration of Mancozeb fungicide and the results of our study were similar to the effect of tricyclazole on Maize seeds (Avinash 2012). According to Anitha \& Savitha (2013), Petit et al. (2012) and Shakir et al. (2016) chlorophyll content were also reduced after increasing the dose of Mancozeb fungicides.

Majid et al. (2014), Singh \& Kaur (2016) and Parween et al. (2016) reported oxidative stress caused by Mancozeb that affect overall plant growth as well as biochemical parameters especially chlorophyll content. It was also reported that higher dose of Mancozeb have negative effect on plant growth and activity of mycorrhizal symbiosis (Saleh 2006, Chaurasia 2014). According to Kackar et al. (1997) and Mirkovic et al. (2015) chronic oral feeding of Mancozeb has produced dose dependent toxicity and death of animal by structural and functional changes like significant increase in thyroid, body weight ratio and histopathological changes. Easton et al. (2001) reported that by the effect of Mancozeb fungicide novel proteins being induced and stress were increased. Some new technology like Nano and PEG applied for Mancozeb claimed much eco-friendly (Majumder et al. 2016). 


\section{CONCLUSION}

From the present study it was concluded that the recommended dose of Mancozeb favours growth of seedlings but concentration higher than recommended dose can be unfavourable for proper growth of plants and chlorophyll content. Further field trial is in process to study the effect of Mancozeb involving other biochemical parameters. Explore the most promising opportunities to increase benefits and reduce health and environmental risk of fungicide use. We should educate and aware the farming community about using the proper quantity of fungicide and adopt eco-friendly practices for sustainable agriculture which is direly needed in the larger interest of planet earth.

\section{REFERENCES}

Aery NC (2010) Manual of Environmental Analysis. Anne Books pvt. Ltd.

Anitha SR \& Savitha G (2013) Impact of Mancozeb Stress on Seedling growth, Seed Germination, Chlorophyll and Phenolic Contents of Rice Cultivars. International Journal of Science and Research 4 (7): 292-296.

Avinash VS \& Hosmani SP (2012) Studies on the Germination and Metabolism of Sorghum seeds treated with Carbendazim. Global Research Analysis 1(5): 3.

Avinash VS (2012) Effect of Tricyclazole on Germination and Metabolism of Zea mays. Nature Environment and Pollution Technology 11(2): 335-338.

Belpoggi F, Soffritti M, Guarino M, Lambertini L, Cevolani D \& Maltoni C (2002) Results of Long-Term Experimental Studies on the Carcinogenicity of Ethylene-bis-Dithiocarbamate (Mancozeb) in Rats. Annals New York Academy of Sciences 982: 123-136.

Benicio MN (2015) Effects of Carboxin + Thiram doses on germination and vigor of three lots broccoli seeds , as well as on the incidence of fungi in treated seed. African journal of Agriculture 2(3): 81-84.

Bensoltane S, Messerer L, Yuobi M, Berrebbah H, Djekoun M \& Djebar MR (2006) Effects of acute and subchronic ammonium nitrate exposure on rat liver and blood tissues. African Journal of Biotechnology 5(9): 749-754.

Bhatia JN \& Gangopadhyay S (2008) Studies on chemical control of white rust disease of mustard. International Journal of Pest Management 42(1): 61-65.

Biswas C, Singh R \& Tiwari RB (2007) Management of white rust (Albugo candida) of mustard (Brassica juncea) by altering sowing date and fungicides. Indian Journal of Agricultural Sciences 77: 626-628.

Cataneo AC, Ferreira LC, Carvalho JC, Andréo-Souza Y, Corniani N, Mischan MM \& Nunes JC (2010) Improved germination of soybean seed treated with thiamethoxam under drought conditions. Seed Science and Technology 38: 248-251.

Chattopadhyay C, Agrawal R, Kumar A, Bhar LM, Meena PD, Meena RL, Khan SA, Chattopadhyay AK, Awasthi RP, Singh SN, Chakravarthy NVK, Kumar A, Singh RB \& Bhunia CK (2005) Epidemiology and forecasting of Alternaria blight of oilseed Brassica in India - a case study. Journal of Plant Diseases and Protection 112(4): 351-365.

Chaurasia N (2014) Effect of locally used fungicide Mancozeb and insecticide profenofos in rice fields of Meghalaya On the soil microflora. International Journal of Pharma and Bio Sciences 5(3): 1049-1060.

Chaurasia RK \& Bhajan R (2015) Genetics of alternaria leaf blight resistance in Indian mustard [Brassica Juncea ( L .) Czern \& Coss.]. International Journal of Environmental \& Agriculture Research 6: 512-514.

Dias MS (2012) Phytotoxicity: An Overview of the Physiological Responses of Plants Exposed to Fungicides. Journal of Botany 2012: Article no. 135479.

Domico LM, Zeevalk GD Bernard LP \& Cooper KR (2007) Acute neurotoxic effects of Mancozeb and maneb in mesencephalic neuronal cultures are associated with mitochondrial dysfunction. NeuroToxicology 27: $816-825$.

Easton A, Guven K \& Pomerai DID (2001) Toxicity of the Dithiocarbamate Fungicide Mancozeb to the Nontarget Soil Nematode, Caenorhabditis elegans. Journal of Biochemical and Molecular Toxicology 15: 15-25.

Elsamen AFM, Goussous SJ, Jendi AA \& Makhadmeh M (2015) Evaluation of tomato early blight management using reduced application rates and frequencies of fungicide applications. International Journal of Pest Management 61(4): 320-328.

FAO (2012) Food and Agriculture Organization Production Year Book. Food and Agriculture Organization of the United Nations, Rome 00100, Italy. 56: 118.

www.tropicalplantresearch.com 
FAO/WHO (1993) Pesticides Residues in Food (Mancozeb). In: Joint FAO/WHO Meeting on Pesticide Residues. pp. 257-289.

Goswami S \& Ghosh S (2012) Hyperparathyroidism: Cancer and Mortality. Indian Journal of Endocrinology and Metabolism 16: 217-220.

Harvest S (2016) Agrochemical manufacturer in China.

Hayes JD \& Paiford DJ (1995) The glutathione-Stransferase supergene family, Regulation of GST and the contribution of the isoenzymes to cancer chemo protection and drug resistance. Critical Reviews in Biochemistry and Molecular Biology 30: 445-600.

Hirve M \& Bafna A (2013) Effect of Cadmium exposures on growth and biochemical parameters of Vigna radiata seedlings. International journal of environmental sciences 4(3): 315-322.

Hollomon DW (2015) Fungicide resistance: facing the challenge. Plant Protection Science 51: 170-176.

Horii A, McCue P \& Shetty K (2007) Enhancement of seed vigour following insecticide and phenolic elicitor treatment. Bioresource Technology 98: 623-632.

Jankowski K (2007) Siedliskowe i agrotechniczno-ekonomiczne uwarunkowania produkcji nasion rzepaku ozimegona cele spo¿ywcze i energetyczne. UWM Olsztyn, Rozpr. Monog. 131: 1-174.

Kabir M, Iqbal MZ, Shafiq M \& Farooqi ZR (2008) Reduction in germination and seedling growth of Thespesia populnea caused by lead and cadmium treatments. Pakistan Journal of Botany 40(6): 2419-2426.

Kackar R, Srivastava MK \& Raizada RB (1997) Studies on rat thyroid after oral administration of mancozeb: morphological and biochemical evaluations. Journal of Applied Toxicology 17(6): 369-375.

Kidwai MK (2007) Isolation, selection and characterization of pathogens of Trichoderma species to control soil borne pathogens, Ph.D. Thesis. University of Lucknow, U.P., India.

Kumar S \& Andy A (2012) Mini Review Health promoting bioactive phytochemicals from Brassica. International Food Research Journal 19(1): 141-152.

Kumar S, Singh D \& Dutta M (2014) Quality characteristics in rapeseed-mustard and role of some antinutritional factors in plant defense: future strategies. Journal of Oilseed Brassica 5: 87-95.

Liu Y, Wang YL, wen HS, Chen MH, Zhang Z, Fu XP, Fu BB, Liao BQ, Lin YH, Q ZQ \& Wang HL (2016) Protective effects of resveratrol against mancozeb induced apoptosis damage in mouse oocytes. Molecular, Reproduction and Development 8(4): 6233-6245.

Majid U, Mahmoodu Z, Siddiqi TO \& Iqbal M (2014) Antioxidant response of Cassia angustifolia Vahl to oxidative stress caused by Mancozeb, a pyrethroid fungicide. Acta Physiologiae Plantarum 36: 307.

Majumder S, Shakil NA, Kumar J, Banerjee T, Sinha P, Singh BB \& Garg P (2016) Eco-friendly PEG-based controlled release nano-formulations of Mancozeb: Synthesis and bioefficacy evaluation against phytopathogenic fungi Alternaria solani and Sclerotium rolfsii. Journal of Environmental Science and Health, Part B 12: 1-8.

Mancini V \& Romanazzi G (2013) Seed treatments to control seedborne fungal pathogens of vegetable crops. Pest Management Science 70: 860-868.

Mandal S, Yadav S, Singh R, Begum G, Suneja P \& Singh M (2002) Correlation studies on oil content and fatty acid profile of some Cruciferous species. Genetic Resources and Crop Evolution 49(6): 551-555.

Manohar RP, Pushpan R \& Rohini S (2009) Mustard and its uses in Ayurveda. Indian Journal of Traditional Knowledge 8(3): 400-404.

Marini N, Tunes LM, Silva JI, Moraes DM, Olivo F \& Cantos AA (2011) Carboxim Tiram fungicide effect in wheat seeds physiological quality (Triticum aestivum L.). Revista Brasileira de Ciências Agrárias 6(1): 1722.

Mathivanan N \& Prabhavathy VR (2007) Effect of carbendazim and mancozeb combination on alternaria leaf blight and seed yield in sunflower (Helianthus annus L.). Archives of Phytopathology and Plant Protection 40(2): 90-96.

Meena PD, Awasthi RP, Chattopadhyay C, Kolte SJ \& Kumar A (2010) Alternaria blight: a chronic disease in rapeseed-mustard. Journal of Oilseed Research 1: 1-11.

Meena PD, Chattopadhyay C, Meena SS \& Kumar A (2011) Area under disease progress curve and infection rate of Alternaria blight disease of Indian mustard (Brassica juncea) at different plant age. Journal of Environmental Biology 44(7): 684-693. 
Miller MD, Crofton KM, Rice DC \& Zoeller RT (2009) Review Thyroid-Disrupting Chemicals : Interpreting Upstream Biomarkers of Adverse Outcomes. Environmental Health Perspectives 117(7): 1033-1041.

Mirkovic B, Tanovic B, Stevic M, Hrustc J, Mihajlovic M, Delibasic G \& Vuksa P (2015) Toxicity of mancozeb, chlorothalonil, captan, fluopyram, boscalid, and difenoconazole to Didymella applanata isolates from Serbia. Journal of Environmental Science and Health, Part B 50(12): 845-850.

Mohammed A \& Alrajhi H (2014) Effects of Amistar and Dithane M-45, a systemic fungicide, on Growth Parameters and antioxidative enzymes of Maize (Zea mays L.). Research \& Reviews: Journal of Botanical Sciences 3(2): 39-46.

Morales M, Moratinos H, Gonzales T \& Madriz P (2012) Effect of fungicides on physiology and health of rice seeds during storage. Revista de la Facultad de Agronomia 29: 505-524.

Nirwan B, Choudhary S, Sharma K \& Singh S (2016) In vitro studies on management of root rot disease caused by Ganoderma lucidum in Prosopis cineraria. Current Life Sciences 2(4): 118-126.

Parween T, Jan S, Mahmooduzzafar S, Fatma T \& Siddiqui ZH (2016) Selective Effect of Pesticides on Plant-A Review. Critical Reviews in Food Science and Nutrition 56: 160-179.

Petit AN, Fontaine F \& Vatsa P (2012) Fungicide impacts on photosynthesis in crop plants. Photosynthesis Research 111(3): 315-326.

Pretty J \& Bharucha ZP (2015) Integrated Pest Management for Sustainable Intensification of Agriculture in Asia and Africa. Insects 6(1): 152-182.

Rangwala T, Bafna A \& Singh V (2013) Effect of Presence of Fungicide on Growth Parameters of Wheat (Triticum aestivum L.) Seedlings. Journal of Biological and Chemical Research 30(2): 529-536.

Rathi AS, Singh D, Avtar R \& Kumar P (2015) Role of micronutrients in defense to white rust and Alternaria blight infecting Indian mustard. Journal of Environmental Biology 36: 467-471.

Saleh AG (2006) Influence of Malathion and Mancozeb on Mycorrhizal Colonization and growth of Zea mays and Vicia faba. World Journal of Agricultural Sciences 2(3): 303-310.

Shakir SK, Kanwal M \& Murad W (2016) Effect of some commonly used pesticides on seed germination, biomass production and photosynthetic pigments in tomato (Lycopersicon esculentum). Ecotoxicology 25: 329.

Singh G \& Kaur D (2016) Studies on the Antioxidative stress responses of fungicides Carbendazim and Mancozeb in seedlings of brassica (Brassica compestris L.). International Research Journal of Environment Sciences 5 (2): 57-62.

Srivastava P \& Singh A (2013) Invivo study of effects of Mancozeb and its metabolite ETU on fish Clarius batrachus. Journal of Biology and Earth Sciences 3(2): 228-235.

Vettorazzi G, Almeida WF, Burin GJ, Jaeger RB, Puga FR, Rahde AF, Reyes FG \& Schvartsman S (1995) International safety assessment of pesticides: Dithiocarbamate pesticides, ETU, and PTU-A review and update. Teratogenesis, Carcinogenesis, and Mutagenesis 15: 313-317.

Vishwanath K \& Kolte SJ (1997) Variability in Alternaria brassicae: Response to host genotypes, toxin production and fungicides. Indian Phytopathology 50(3): 373-381.

Windham AS \& Windham MT (2004) Chemical control of plant diseases. In: Plant Pathology: Concepts and Lab Exercises. CRC Pub., USA. 